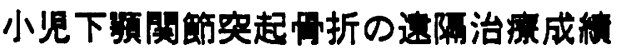

\author{
村上是一郎・即虫忠・野瀨将洋・上谷和人 \\ 足立 尚・藤田茂之・松木優典・兵行忠

\section{Long-term follow-up study in pediatric patients with mandibular condylar fracture}

\author{
Ken-Ichiro Murakami - Tadahiko Irzuka - Masahiro Nose - Kazuto Kamitani \\ Hisashi AdachI - Shigeyuki FujITA - Masanori MAtsuki • Yukitada Hyo
}

\begin{abstract}
Long-term follow-up study was done on eight patients in child age with mandibular condylar fracture. A conservative treatment was done on five cases, and surgical reduction was carried out on three patients. The ages of patients at trauma were distributed from 6 to 14 years old, and the average follow up period was 7.5 years. The criteria for assesment of the posto-perative jaw function is classified into four groups: Excellent, fair, poor, and no good (Nakatomi, 1964). Four cases were evaluated "excellent", two "fair" and two were assessed "poor".

Deviation-type fracture (MacLennan, 1952) in association with suspected pressured injury on the condylar surface seemed to have a closer relation to the poor result than the Dislocation type. Two chronic-case patients were included in the patients of Deviation type fractured group. Between the surgically-treated and conservatively cared patient groups, there is no obvious difference in the clinical course.
\end{abstract}

Key words: mandibular condylar fracture in children, long-term follow-up

粕言

日常臨床において，小児の下䫅関節突起骨折の取り扱 いはしぱしば問題となる，小児の下䫑関節突起骨折に関 する遠隔成績は MacLennan ${ }^{1)}$, Leake ${ }^{2)}$ ，Hall ${ }^{3)}$ らを始 めとして本邦では 清田 ${ }^{4)}$ ，西䳋ら5゙ とよっても保存的治 療によりおおむね良好な成績が得られたとされ，最近で (中中村(3)，太田と茂木7)がそれぞれ保存㞠法例の良好な 長期の遠隔成績結果を報告している.

しかしまれには下頞頭の損傷が同部に拘縮や強直を招 来して䫇発育異常による靧変形症を後遺したり ${ }^{8)}$, 軽度 から重度の下䫑運動障害を後遺することからその取り扱 いには十分, 注意する必要がある.

京都大学医学部口貯外科学教室

（指埒：飯塚忠彦助教授）

Department of Oral and Maxillofacial Surgery

Faculty of Medicine, Kyoto University (Acting

Director: Assoc. Prof. Tadahiko Iizuka)

受付日：昭和62年 9 月 7 日
本研究では，過去に当科において加療を行い，追跡調 查の可能であった 8 症例の小巟下額関節突起骨折の遠谝 成紸につき検討したので報告する.

\section{対象と方法}

本研究では過去10年間に当科を受診し，初診時の資料 の整った，口葴以下の小児の下額関節突起骨折 9 症例を 対象として, フンケートKよる予後調查ならびにリコー ルによろ診査およびX線学的再診査を実施し, 調査の可 能であった 8 例の 遠隔成績について検討した（表 1 ）. 予後判定はX線検査による骨折部の治㾀状態，ならびに 罰運動の状態と自他覚症状について検討し，特に機能的 評価を重視する立場から中富による後遺障害の判定基 準日)（表 2）を予後判定に準用した。

\section{結果}

受㥂時年龄は 6 歳から 14 瓷で, 骨折型では MacLennan の分類 ${ }^{0)}$ で I 型の 偏位骨折が 4 例 4 側, IV 型の脱 


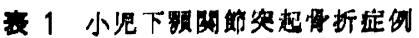

\begin{tabular}{|c|c|c|c|c|c|}
\hline 提例 No. & 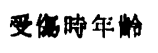 & 性 別 & 骨 折 型 & 処目までの期的 & 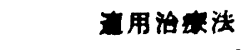 \\
\hline 1 & & 男见 & 右侢位型* & 1 日 & 是问固定 \\
\hline 2 & & 男先 & 左偏位型 & 12日 & レシン床同子 \\
\hline 3 & & 男觉 & 右俩位型* & 8 遇 & レシン床四子 \\
\hline 4 & & 男先 & 阔側枟位型* & 3 日 & 明因定 \\
\hline 5 & & 女児 & 左枟位型 & 3 日 & 资问固定 \\
\hline 6 & & 女㫛 & 右枟位型 & 19日 & 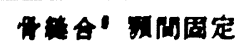 \\
\hline 7 & & 女见 & 右佩位型 & 3 か月 & レシン床田子+ \\
\hline 8 & & 女㫛 & 左転位型 & 2 进 & 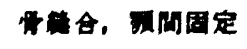 \\
\hline
\end{tabular}

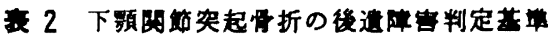

\begin{tabular}{|c|c|c|}
\hline & 自党症状 & 他党定 状 \\
\hline 完全洽鬼 & 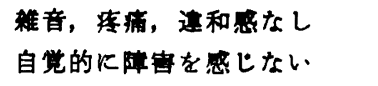 & 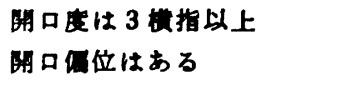 \\
\hline 障害 I & $\begin{array}{l}\text { 雑音, 速和感あってもよい } \\
\text { 日常生活に不自由を感しない }\end{array}$ & （閐口制限おり $2 \sim 3$ 梳指） \\
\hline 障宫 II & 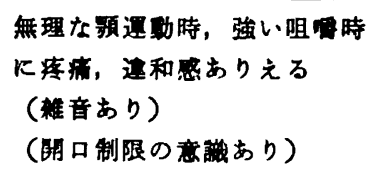 & 閶口度 2 棈指程度 \\
\hline 碚菑 I & 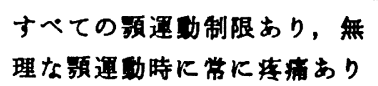 & \\
\hline
\end{tabular}

(中寡, 1964)"

臼骨折が 4 例 5 側で，両側性は 1 例であった，処㯰飞至 る期間では 8 週あるいは 3 か月の陳旧例もあったが，多 くは 2 週間前後に処置を受けていた，処䁂別では 5 例に 顥間固定，あるいは床副子に下額骨囲繞結絷を併用した 保存療法を実施し，3例には覞血的整復術を逗応した。

遠隔成績の期間は最短 2 年 1 か月, 最長 10 年 6 か月 で，予後判定は中富の分類で完全治稂が 4 例，障害 I が 2 例，障害IIが 2 例であった（表 3 ）。

\section{症例と X線学的锤家}

症例 4 : 保存療法を行った受㥂時年踰 6 歳男児の両側 性 MacLennan IV 型, 両側の枟位脱目骨折例を示す(写 １）。併発した正中部骨折に対しては骨程合を行い， 䫇間固定を 2 週間の後, 早期の開口練習を実施した。術

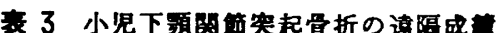

\begin{tabular}{|c|c|c|c|}
\hline 症何 & 骨折型分彩 & 于嵝 & 判定期间 \\
\hline 1 & 右 II 型 & 䤃 I & 10年 6 か月 \\
\hline 2 & 左 II 型 & 神富 II & 10年 4 か月 \\
\hline 3 & 右 II 型 & 陣裳 II & 7 年 \\
\hline 4 & 䍓侧 $\mathrm{N}$ 型 & 完全治空 & 5 年 2 か月 \\
\hline 5 & 左IV型 & 完全洽点 & 2 年 1 か月 \\
\hline 6 & 右IV㤠 & 完全治第 & 9 年 6 か月 \\
\hline 7 & 右 II 型 & 倩宫 I & 8 年 \\
\hline 8 & 左 V型 & 完全治管 & 7 年 5 か月 \\
\hline
\end{tabular}

- MacLennan (1952) ${ }^{8)}$ 


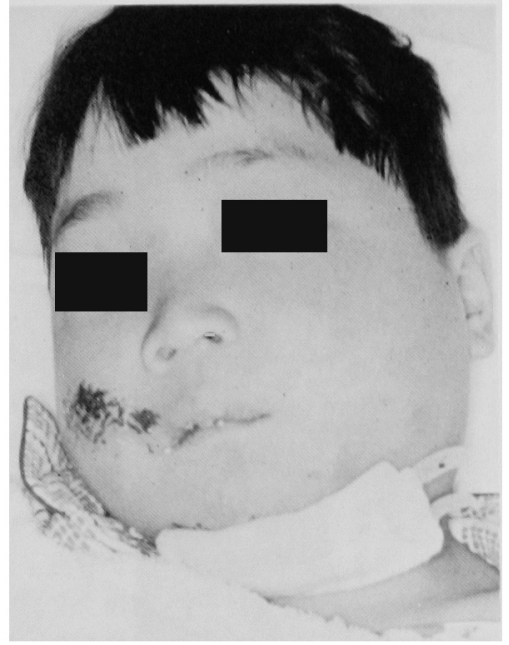

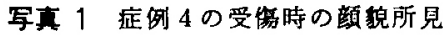
(6 歳時)，両側阙節突起部骨 折, 転位脱臼例。

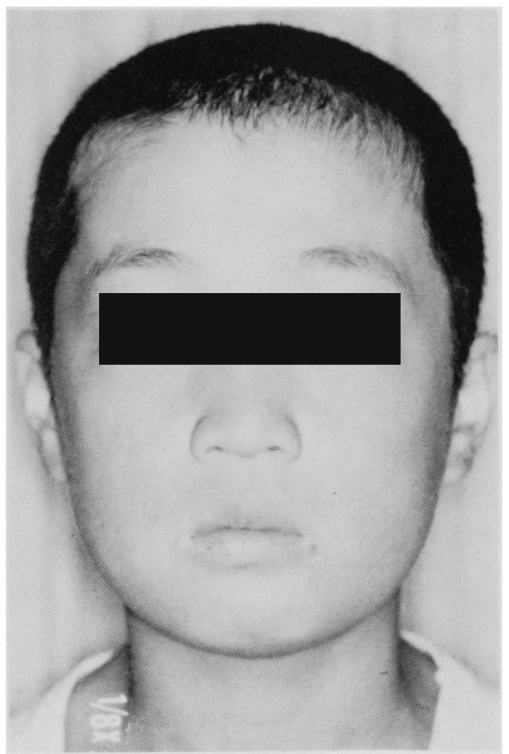

写直 2 同症例 5 年 2 か月後の所見. 顎变形なく咬合状態。良好， 開口度は $49 \mathrm{~mm}$ ある。

啳 5 年 2 か 月の顔貌所見では，顔面の変形なく咬合状態 も良好である (写真 2 ). 開口度は $49 \mathrm{~mm}$ で両側とも下 顎頭の動きは良好である. 受傷時ならびに 5 年 2 か月後 のX楾所見を示寸 (写真了). 前内側へ脱臼していた下 顎頭はほぼ正常な位置に復している. 予後判定は完全治

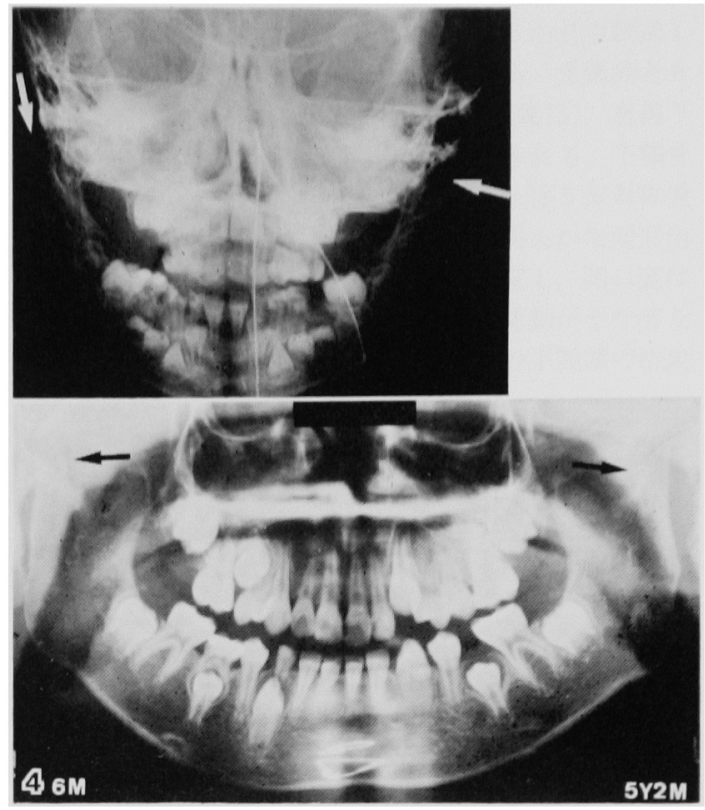

写式 3 受僨時の下颚骨 P-A 所見（上段）矢印は 两側の骨折部を示す，正中部にも骨折線が みえる（写真の中で白くみえるラインは マーゲンソンデ)

下段は 5 年 2 か月後のハノラマ所見，両側 の下買頍は变形しつつも下額営に対して良 好な位置にある。
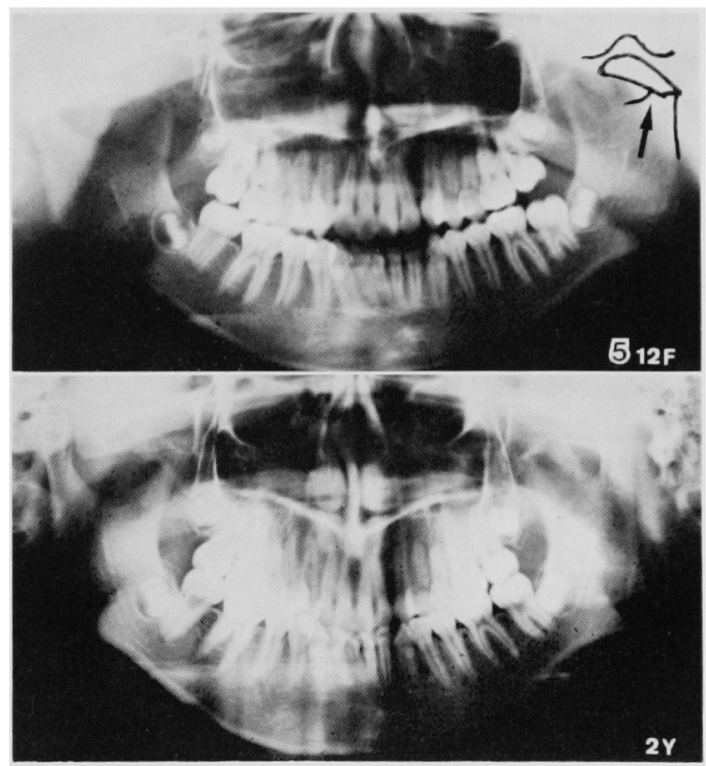

写真 4 症例 5 の受借時のハノラマ所見を上段に， 2 年後の同所見を下段に示す。 


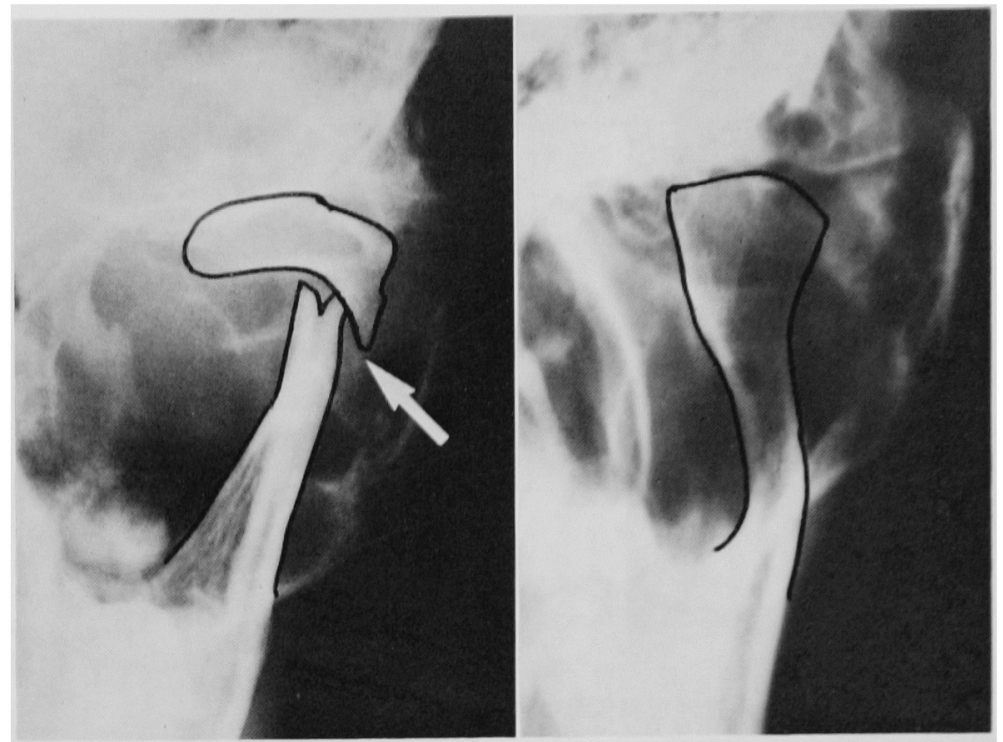

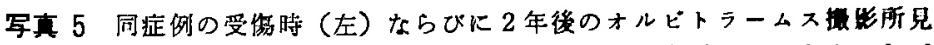
(右).内侧への転位脱臼のみられた下頻謴は变形しつつb立ちあが ってみる。
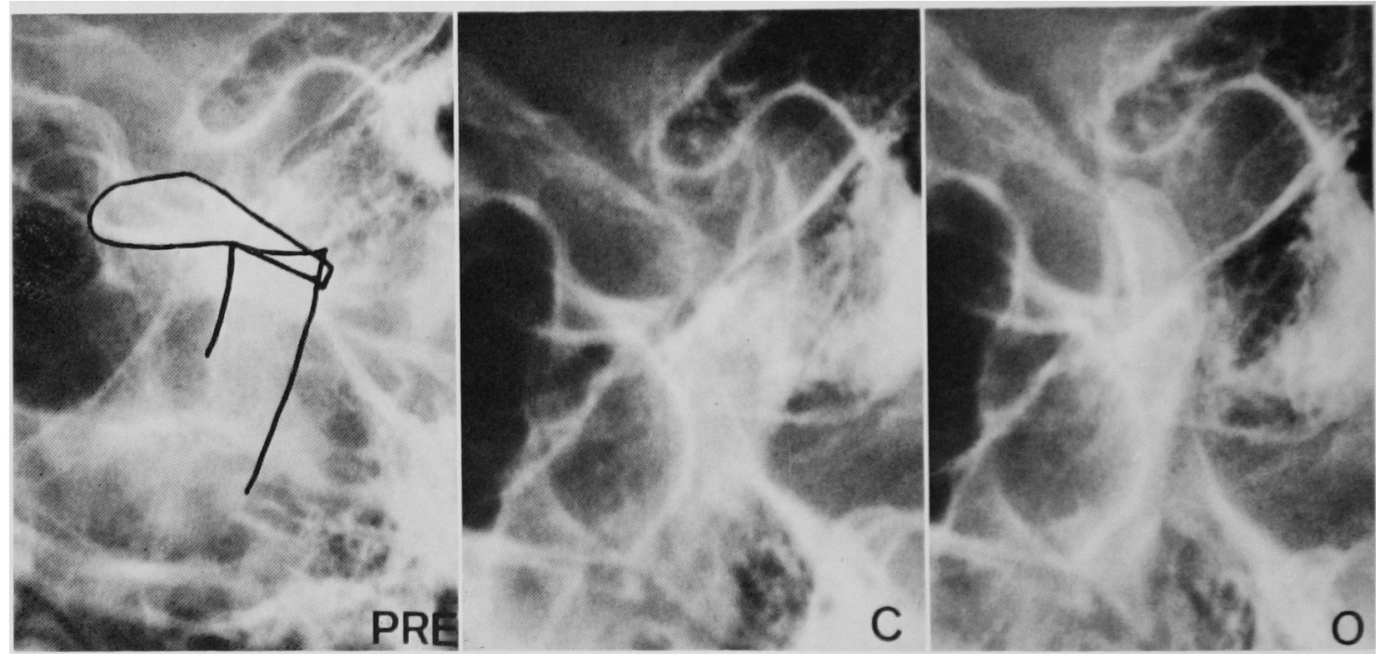

写真 6 左より，受筋時， 2 年後の閉口時 $(C)$ ，開口時（O）のショーラー氏X線所見を示す。開口時に 下顎頭は関節結節下まで上く滑走しているのがみえる。

隂.

症例 5：四歳女児の MacLennan IV 型, 左側の転位 脱臼例で，患側の囦部間にシリコンプロックを挿入し て䄪 2 週間の靧間固定を行った症例である. 2 年後のパ ノラマX線所見では脱臼していた下頡頭は正常位に戻っ ている (写真 4 ). 同症例の術後 2 年 1 か月のオルビト ラームスによるX 線所見 (写真 5 ), シューラー氏法に
よる開閉口時頡関節所見 (写可 6) を示す.X線学的に は軽度変形治庩と考えられるが機能的には良好な释過を たとっており，予後判定は完全治䉥とした。

症例 6 : 口歳女览例，右側の転位脱目骨折で MacLennan $\mathbb{V}$ 型例. 下靧は軽度の前突位で開口障害を認め

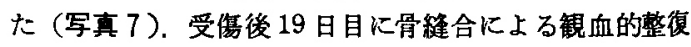
固定を行った，本症例では下䫑頭は1度，摘出され，再 


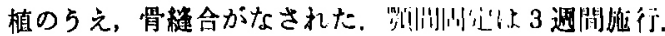

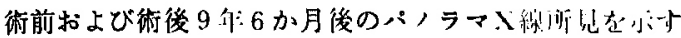

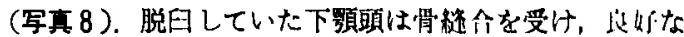

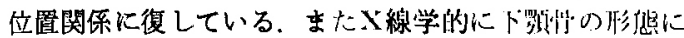
異常は認められない，同症例のオルビトラームスによる

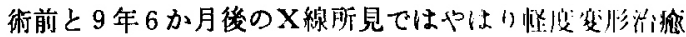
の状熊を呈している（写真9）、シュー-;ー1飞江：による

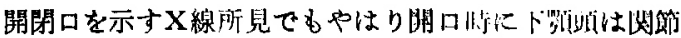
結節の下端に至り，正常な沜术逃的がみられる（写直 10). 本症例では，再植した下罰頭は败収されることな

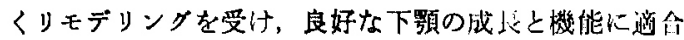

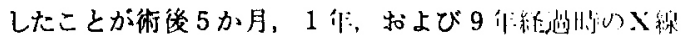
所見かららかがかれる（写真 11）。圲住，牧合状的，下

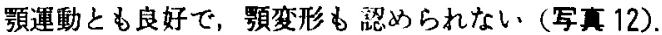
予後判定は完全治瘾.

症例 7：口歳女児例, 右側 の MacLennan II 型偏位

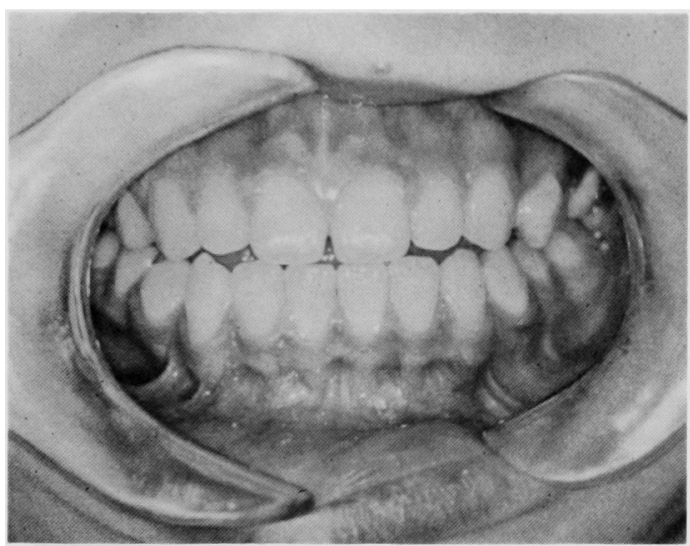

写真 7 症例 6 の受侮時 (13歳時) の咬合状態, 柽 度の前突状態を呈し，開口制限がある。

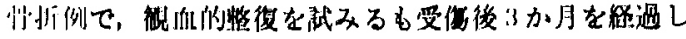

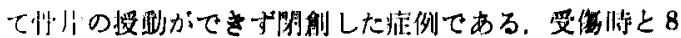

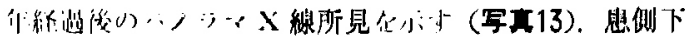

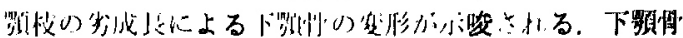

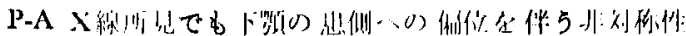

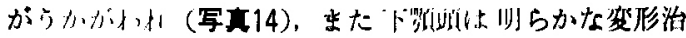

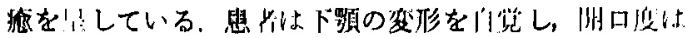
$48 \mathrm{~mm}$ で開题ないものの则侧への仙方速政がやや少り

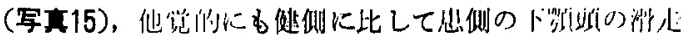

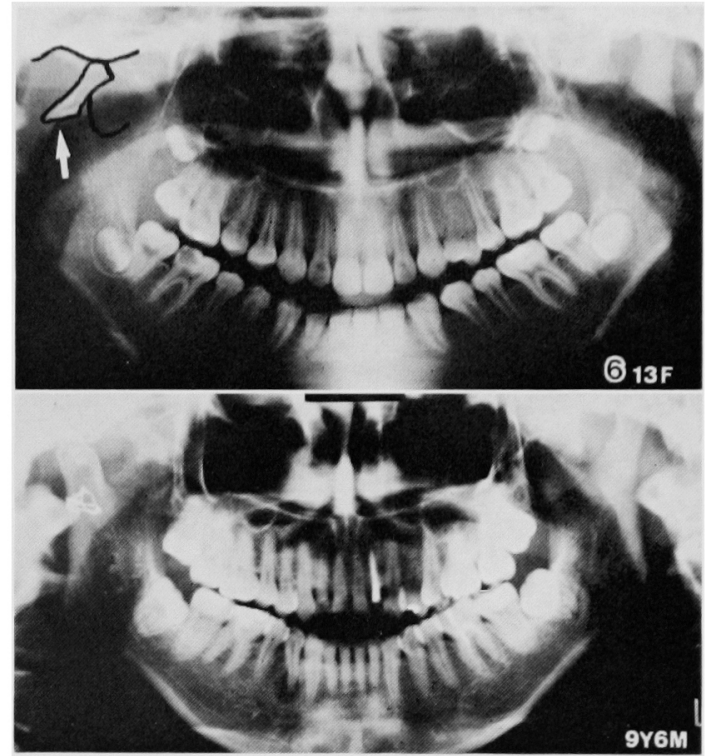

写真 8 受賃時 (上段) と 9 年 6 か月後 (下段) の ヘノラマ所見を示す，下䫚枝，下類骨体と もに変形を認めない。

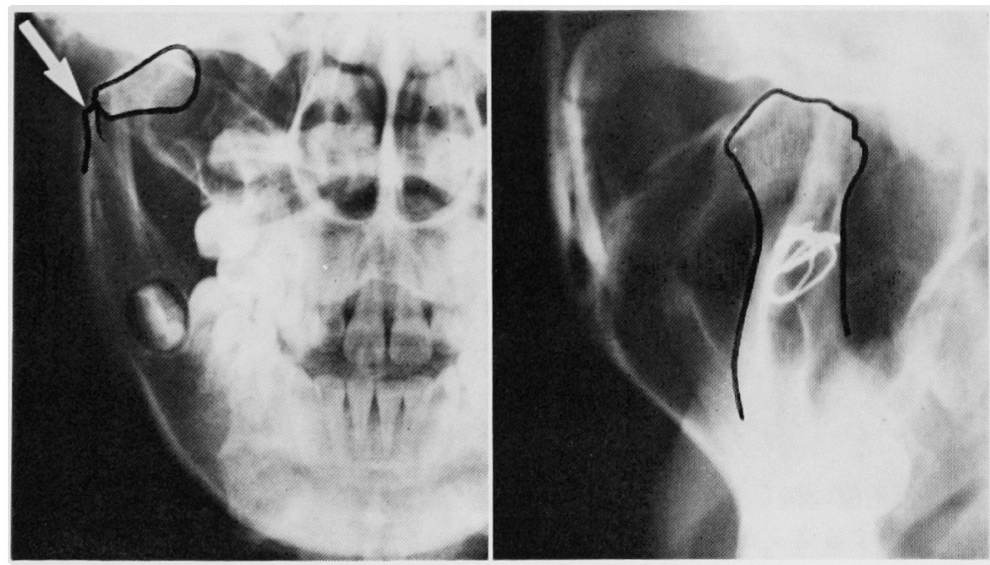

写真 9 受偒時（左）と 9 年 6 か月後（右）のオルビトラームス所見を示す。 下顎頭は軽度変形治虑の像を呈する。 


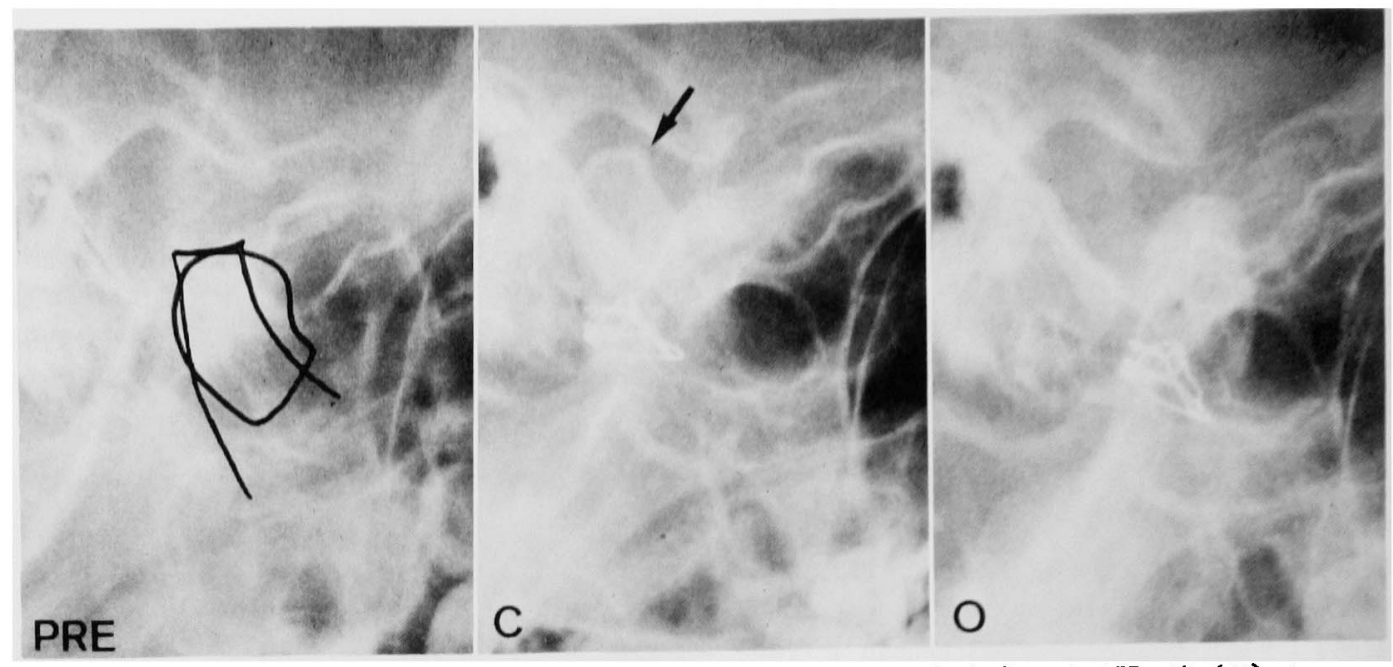

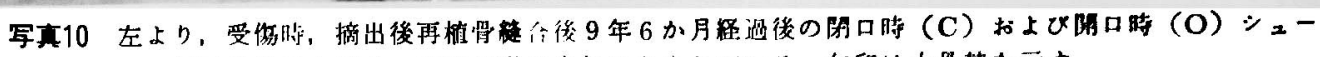

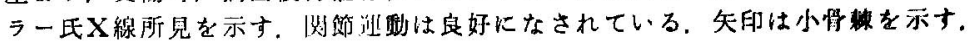

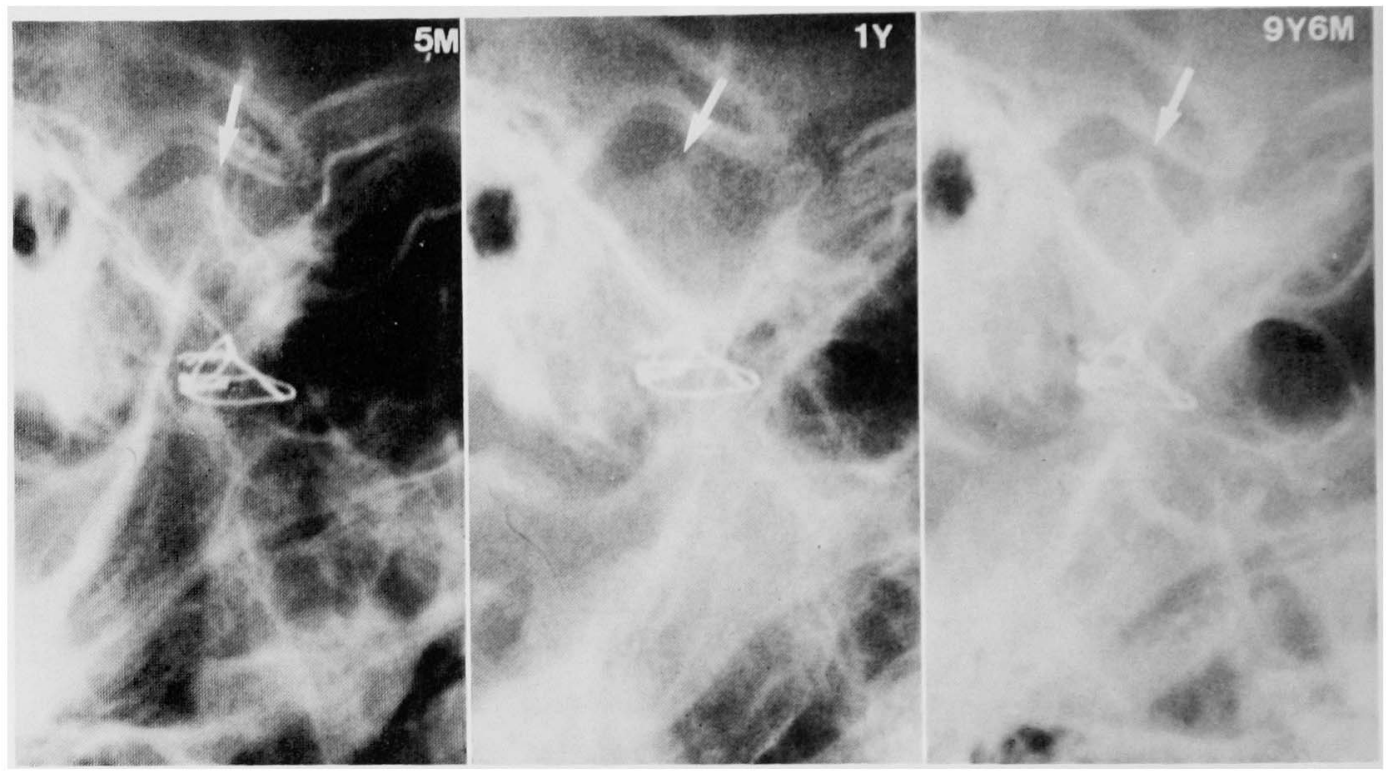

写真11 左上り，再植骨桻合後 5 か月，1年，それに 9 年 6 か月後の閉口時シェーラー氏X線所見を示す。 当初にみられた下額頭の著明な变形は程過ととるに正常な形に近ついている.

運動制限が認められた。予後判定は障害 Iとした。

考察

小傴の下顎関節突起骨折治療に際しては，下顎頭に下 罰の growth center が存在する考えから、同部への侵 意は最少限に留めるぺきだとて，原則的に保存的療法 が推奨されている12,13)，実際，これまで多く報告され
ている遠隔成績です MacLennan 51) 6 症例のすべて が良好に程過し，Leake ${ }^{2)}$ 発育障害をみなかったと述 へ， MacGregor ${ }^{3)}$ は 13 例中粉砕骨折例の I 例に軽度の 顔貌の変形を伴う発育異常をみるのみであったとし，ま た Hall ${ }^{32}$ の 21 例の遠谝成耫でも 1 例の強直症を見い出 すのみである，本邦でも清田"，西嶋らうばれそれ 9 例， 6 例の遠隔成績で，前者で軽度の顔貌の変形を 2 例 にみるむ機能的には問題なく，また後者では中富の判定 


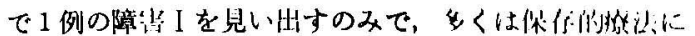

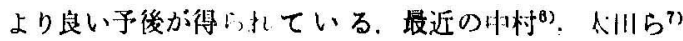

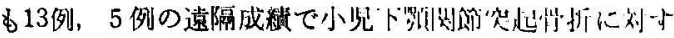
る保存的蟟法の妥当珄を評洒する䋐果となっている.

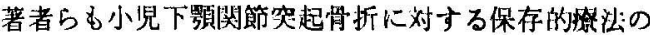
適用については意見を共にしたい，しかしそれは外科镣

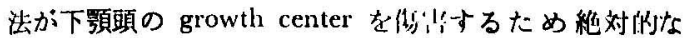

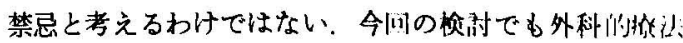

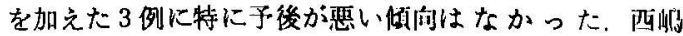

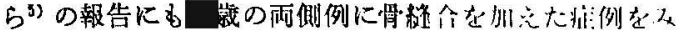

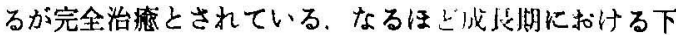

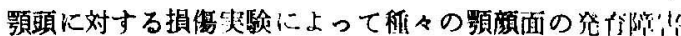

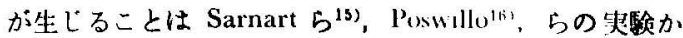
らも明らかで，本邦です久保田 ${ }^{(7)} や$ 野 $^{18)}$ がそれぞれて 幼弱犬るいはラットを用いた実験的検討によって発 育障害が生じたことを報告している，しかし一力で，

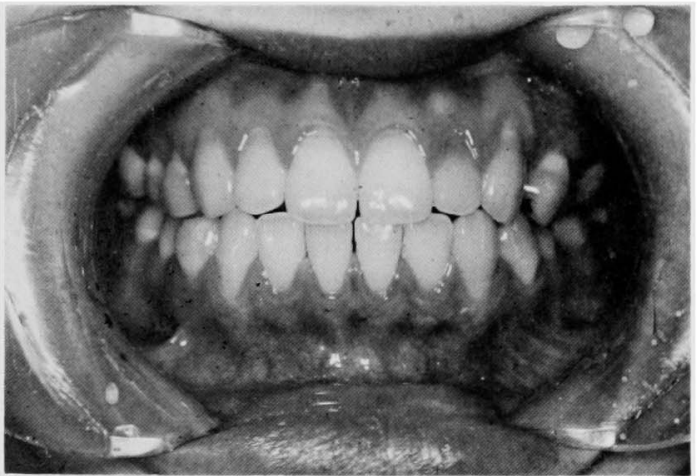

写真12リコール時の咬合状態を示す。形態的，機 能的に良好な経過をみる。

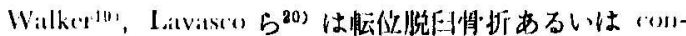

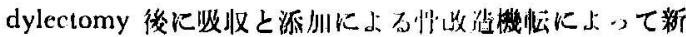

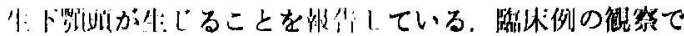

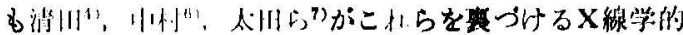

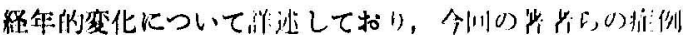

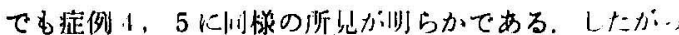

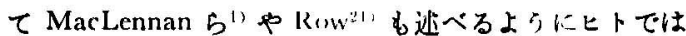

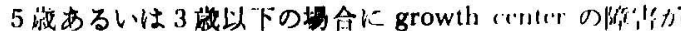

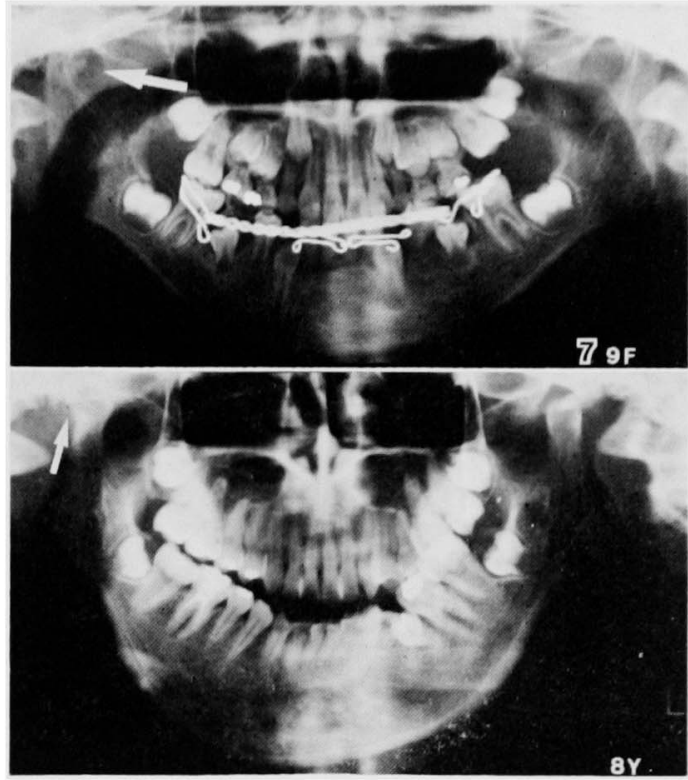

写真13 症例 7 の受伤後床副子装着直後（上段）と 8 年後 (下段) のハノラマ所見を示す，下 䫇頭は偏佃骨折を呈し，8年後の所見では 同部の変形が著明である。

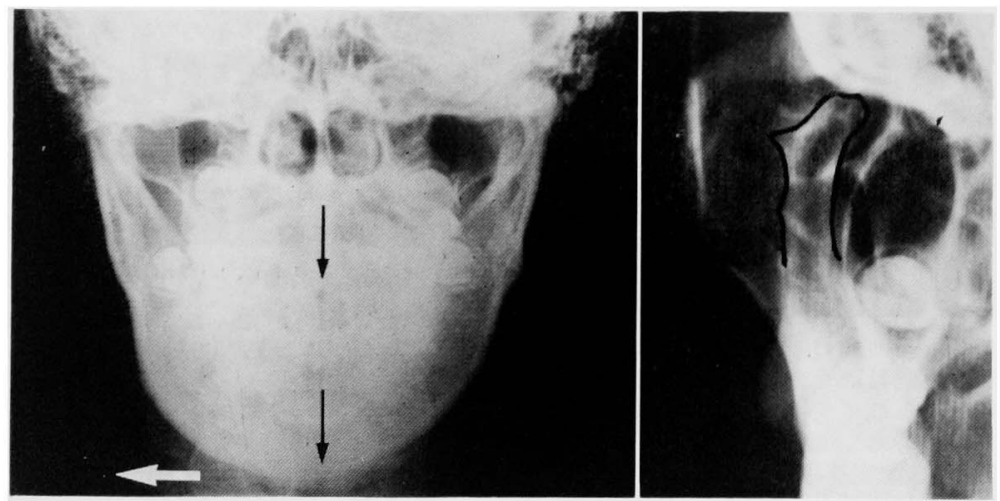

写真14 同症例リコール時の下頻骨 P-A 所見とオルビトラームス撮影を示 す。下頧骨は患側（左㑡）へ偏位し，下顎頭は著しい変形治湾を呈 している。 


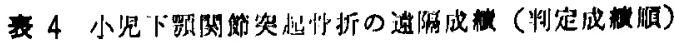

\begin{tabular}{|c|c|c|c|c|c|}
\hline 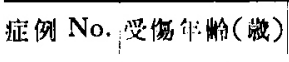 & 晠折留 & 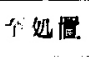 & 图定 & \multicolumn{2}{|c|}{ 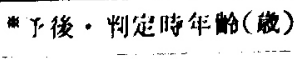 } \\
\hline 4. & 阿 $N$ & 311 & IMF & 完治 & 11 \\
\hline 5. & 左 $N$ & 311 & IMI: & 芯治 & 11 \\
\hline 6. & 保V & 1911 & * $1 \mathrm{MI}+\mathrm{iow}$ & 完治 & 22 \\
\hline 8. & $1: \mathbb{N}$ & 1411 & $\mathrm{IMl}+\mathrm{iow}$ & 完治 & 13 \\
\hline 1. & 隹 & 111 & $1 \mathrm{ML}$ & 障的 I & 24 \\
\hline 7. & fill & 3 月 & 布时子 & 㳻保 I & 17 \\
\hline 2. & $y_{1}:$ II & $12 \mid 1$ & 快利子 & 陆斘 II & 17 \\
\hline 3. & 右 II & 8 䢞 & 戊副子 & 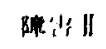 & 17 \\
\hline
\end{tabular}

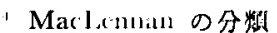

*中富の判定
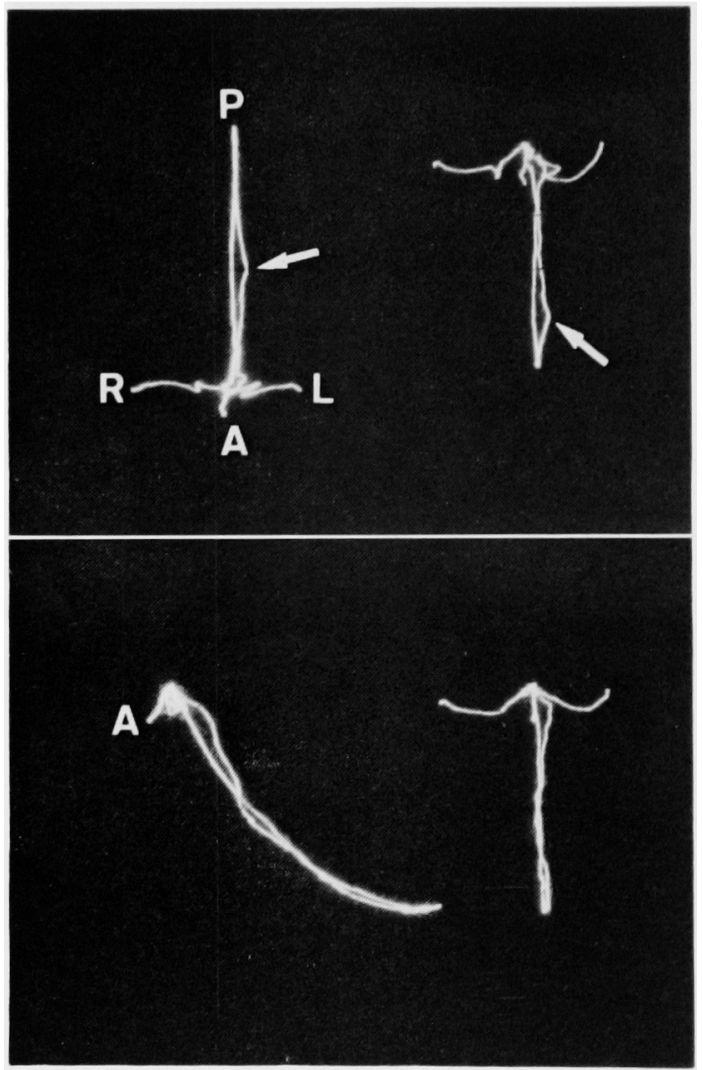

写真15症例 7 のコール時の MKG 所見。下䫇 切菌の限界運動做跡を水平面之前額面投影 像（上段）ならびに矢状面と前額面(下段) で示す。開口時に左側顎関節にクリックが ある(知印)，前突運動にやや制限があり， また対側への側方運動が患側への動きに比 べて劣っているのがわかる。

A: Anterior, P: Posterior, L: Left, R: Right

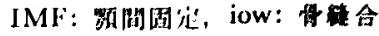

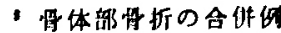

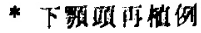

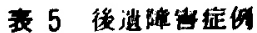

传 这 征

症侧 No. 判 定

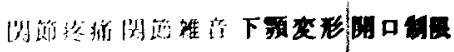

1. 障宫 I

$7 . \quad$ 障菑 !

2. 陣害 II

3. | 障害 II

㫫念され，その際にさらに加えられるよ5な局所への外

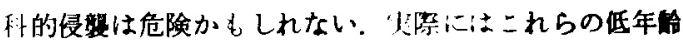
児に外科的療法が適応となるのはごくまれと考引られ， Sanders ${ }^{12)}$ があげるよ5な骨折骨片が後伐的に下頻連動 を障害するよらな場合に限られるであろら。これらから， 『外科療法が下額頭の growth center を期害するゆえに 絶対的な禁忌』と考えるわけではないと述へたたか，今回 の遠隔成绩結果では外科的療法群が保存㞠法群の成耫よ り高くはなかった，その成嘖が同珵度であれば，手術に 伴ら皠々のリスクを考虑すれば保存㞠法が第一義的に選 択されるべきであろら。

今回の遠隔治療成精結果を撩法別ではなく，その予後 の差により分けたものを表 4 に示す.今回の結果からは 脱田例である MacLennan VV型の方が偏位例であるI 型よりも子後が良いといら，成人の应例の場合22-21) とは 逆の結果が得られた。この中富の後遗障害 I，II と判定 された 4 症例の受㑺時X楾所見を示す(写索16). 症例 1 は通常の偏位骨折だが，他の3 例は下顠頭が圧迫骨折 の状態を呈する屈曲骨折の所見を呈している，表 $5 に$ れらの症例の具体的な後遺症状を列記する. 多くは患側 の crepitus 様の雑音を伴った運動制限があり，また反 対側の clicking を訴点る症例，また患側下䫈枝の発育 不全に伴ら軽度の下顎の変形を自覚する例は应例 1 をの 


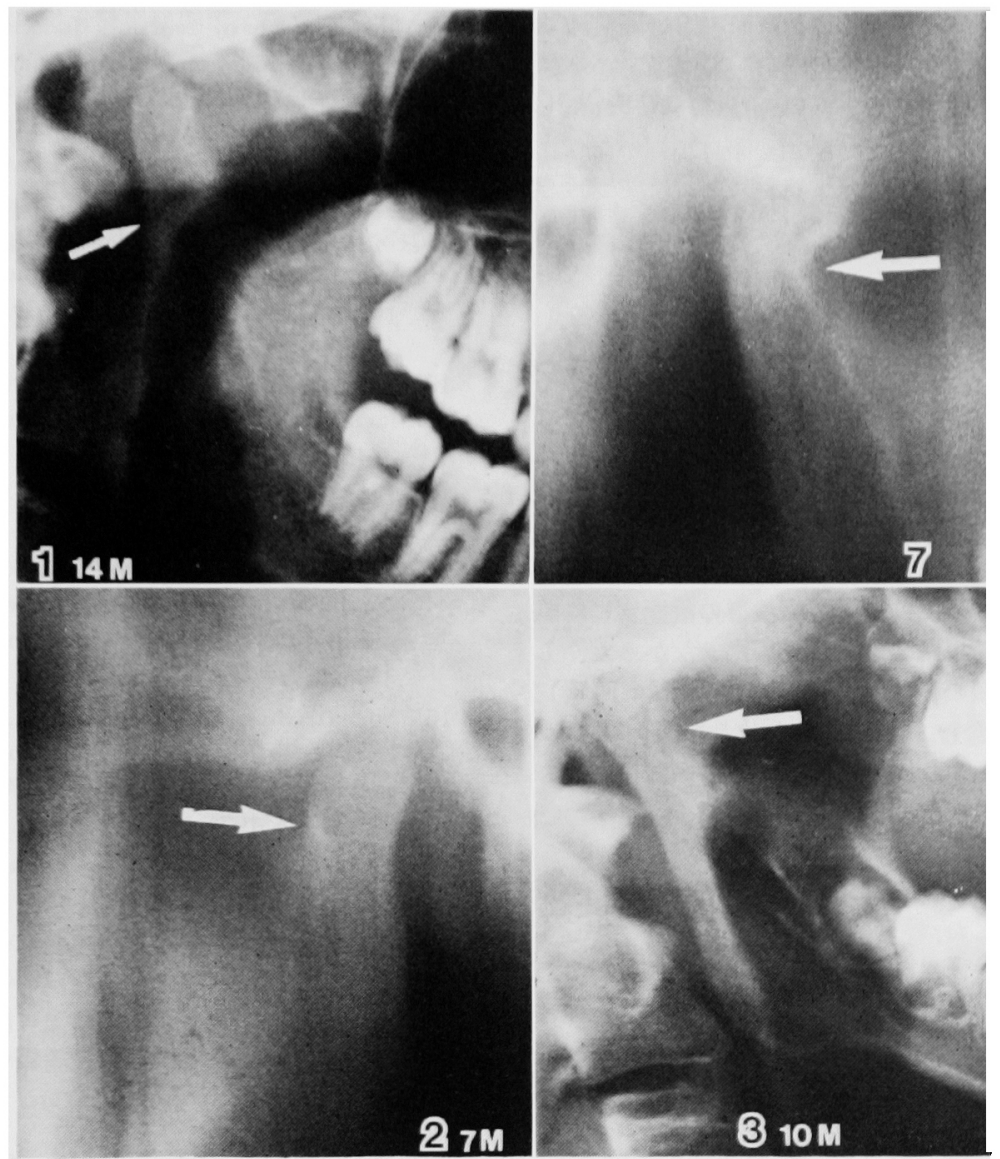

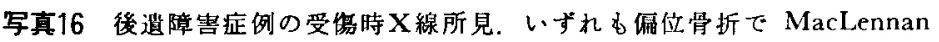
II 型を呈している，症例 1 の藏男児侧（左上），症例 7 の口慼女

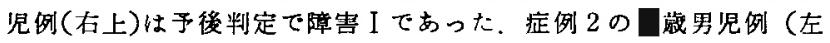

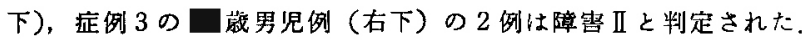
症例 1 をのそいて他の3 例は小児にみられる届曲骨折像を呈してい る。(知印は各症例の骨折部を示す)

ぞく3例のすへてにみられた，先にも触れたよ5に買顔 面の成長発育に関する多くの研究によると，下面頭がそ の成長発育の主要な役割を果たしているといわれ, 顎関 節の損傷の病態と修復に関する詳細な研究が展開されて いる ${ }^{25)}$ ．しかし下顎頭が成長の第 1 の中心なのか，あ るいは下顎骨が顔面の軟組織器質の成長に二次的に反応 して成長する ${ }^{26)}$ のかについてはまだ議論の分かれるとこ ろである．しかし下靧頭軟骨が他の四肢の骨端軟骨のよ らな柱状構造を示していないことは下顎頭軟骨に様々な 方向に成長し得る能力があると一般には認識され ${ }^{25)}$ ，さ らに下影頭軟骨は1次的成長中心というよりはむしろ適 応成長の場における改造中心と考支られるべきであ万ら とする Durkin らの示唆27)は今回の小児骨折の骨折型の
差による遠隔成績の差の解釈に興味深い示唆を与える。

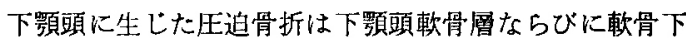
骨梁に挫減創のよらな損信を与え，そのことはりモデリ ング能の阻害ないしは抑制的に働き，その結果，下䫟頭 の顔面の軟組織器質の成長に対する反応が抑制され，下 罰骨の成長抑制が生じたのではないかといら考察もでき る.もちろん，損傷を受けた下顎頭軟骨の再生能につい

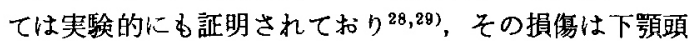
形態と機能の回復に対して致命的ではありえないしか 乙，特に症例 7，3 亿みられた当初の機能訓練の遅れ は組織の修復過程に対する一層の抑制的因子と考えら れ30)，その予後成續に関わったことと思われた。

今回の遠隔成績結果では受傷時年跲での差はなかっ 


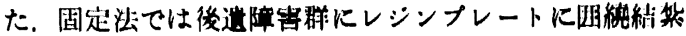

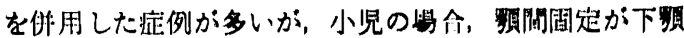
機能の予後に有利に作用したとは思えない，いずれにし ろ正確な咬合の回復に加えて，早期の開口剽練がなされ ていることがりり重要であったと思われる。

\section{結浯}

小児の下嵿関節突起骨折 8 症例の平均 7 年 5 か月にわ

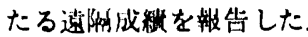

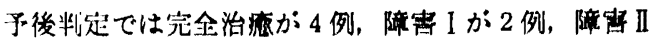
が 2 例であった。

下額顽は全例でX線学的に㹩度から中度の变形治㾀を 呈していた。

遠隔成猜では保存療法群，外科潦法群の治㙩别には差 はなく，また受賃時年秢でも差は見い出せなかった。し かし骨折型で下顎頭の転位骨折群 (MacLennan $\mathbb{V}$ 型) より，压迫骨折を含む，下顥頭の偏位骨折症例（MacLennan II 型) でより後遭障害を認める㑯向があり， この中には 2 例の陳旧例が含まれていた。

本論文の要旨は第39回日本口腔科学会総会（仙台市） に扎いて口演発表した。

また本報告に当り，恩師故小野尊睦教授には絶えす通

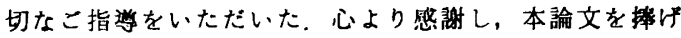
たい.

\section{引用文献}

1) MacLennan, W.D. and Simpson, W.: Treatment of fractured mandibular condylar processes in children. Brit J Plast Surg 18: 4234271965.

2) Leak, D., Doykos, J., et al.: Long-term follow-up of the fractures of the mandibular condyle in children. Plast Reconstr Surg 47: 127-131 1971.

3) Hall, R.K.: Injuries of the face and jaws in children. J Oral Surg 1: 65-75 1972.

4）消田健司：小児影骨骨折に関する臨床的ならび にX線学的研究。口病誌 43: 479-508 1976.

5）西嶋克已, 石田利広, 他：過去10年間当教室に 扣ける顎関節突起骨折患者 123 例の臨床統計的 観察。科誌 27: 343-352 1978 .

6) 中村雅明：小児頢骨骨折の臨床的研究。日口外 誌 31：2297-2316 1985.

7）太田 舜, 茂木敏雄：小坚額関節突起骨折の予 後について。 日外誌 32：1018-1029 1986.

8) Adekey, E.O.: Pediatric fractures of the facial skelton; a survey of 85 cases from Kaduna, Nigeria. J Oral Surg 38: 355-358 1980.

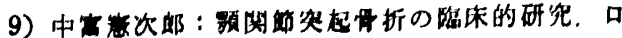
科鲇 13: 132-155 1964.

10) MacLennan, W.D.: Consideration of 180 cases of the typical fractures of the mandibular condylar process. Brit J Plast Surg 5: 1221281952.

11) Sarnat, B.G.: Clinical and experimental considerations in facial bone biology: Growth, remodeling and repair. JADA 82: 876-889 1971.

12) Sanders, B (Ed): Pediatric Oral and Maxillofacial Surgery. Mosby, St Louis, 1979, p 362374.

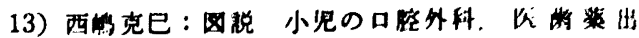
版, 來京, 1979, p 85-108.

14) MacGregor, A.B. and Fordyce, G.L.. The treatment of fracture of the neck of the mandibular condyle. Brit Dent J 102: 3513571957.

15) Sarnat, B.G. and Muchnic, H.: Facial skeltal changes after mandibular condylectomy in growing and adult monkeys. Amer $\mathbf{J}$ Orthod 60: 35-45 1971.

16) Poswillo, D.E.: The late effects of mandibular condylectomy. Oral Surg 33: 500-512 1972.

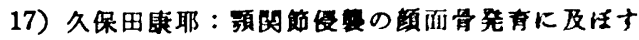

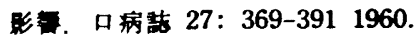

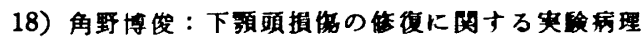

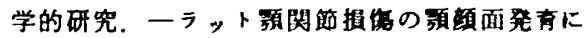
及ばす影を中心にして一、科誌 32:691091983.

19) Walker, R.V.: Traumatic mandibular condylar fracture dislocations. Effect on growth in the macaca rhesus monkey. Amer J Surg 100: 850-863 1960.

20) Lovasko, J.H. and Laskin, D.M.: Facial growth after condylectomy and alloplastic condylar replacement. J Oral Surg 36: 6856921978.

21) Rowe, N.L.: Fractures of the jaws in children. J Oral Surg 27: 497-507 1969.

22）久保四郎，村橾 姜, 他：預関節突起骨折 124 例に対す万臨床的㭘討，特にその分類につい て. 日外誌 29: 1794-1805 1984.

23）岡達，金田敏郎，他：下預関節突起骨折 の予後に関する研究。日外誌 22：793-800 1976.

24）松木侵典，村上目一郎，他：遇去10年間の下䫑 関節突起骨折に関する校討，(2) 高位骨折例の 予後钼察，特に锶血的整復症例について（抄）. 日只外誌 30: 20021984.

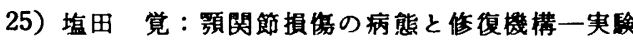
的研究とその展望一，金医大誌 10(Supp)： 134-143 1985.

26) Moss, M.L. and Salentijin, L.: The primary 
role of functional matrices in facial growth. Amer J Orthod 55: 566-577 1969.

27) Durkin J.F. Heeley, J.D., et al.: The cartilage of the mandibular condyle. Oral Sci Rev 2: 29-99 1973.

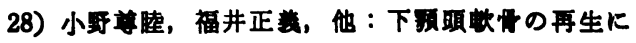

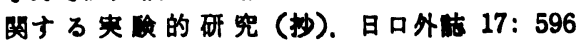

1971.

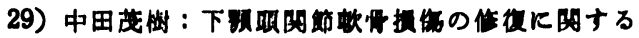
央的研究. 日只外体 29: 239-252 1983.

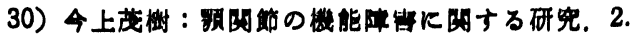

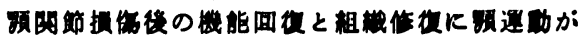

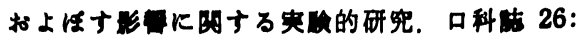
431-450 1977. 